\title{
Computer Crimes in the Jordanian Society: Ajloun/Empirical Study
}

\author{
Mohammad. M. Hussainat ${ }^{1}$ \\ ${ }^{1}$ Department of Social Sciences, Ajloun University College, AL-Balqa Applied University, Jordan \\ Correspondence: Mohammad. M. Hussainat, Department of Social Sciences, Ajloun University College, \\ AL-Balqa Applied University, Jordan. E-mail: mohammadhussainat@yahoo.com
}

Received: April 12, 2013 Accepted: May 16, 2013 Online Published: June 28, 2013

doi:10.5539/ass.v9n9p85

URL: http://dx.doi.org/10.5539/ass.v9n9p85

\begin{abstract}
The study aimed identifying the most important computer crimes and Internet in the Jordanian society, has emerged from this main objective questions are: 1) What is the size of the breakthroughs that crimes committed on the Internet? 2) What is the size of the financial crimes committed on the Internet? 3) What is the size of crimes create or attend or participate in the opposition or hostile websites committed on the Internet? 4) What is the size of piracy crimes committed on the Internet? The sample of the study. It consisted of (50) individual youth(Males and Females).Order to answer the first question and the second, third and fourth were used averages and standard deviations and ranks with the aim of identifying the most common Internet crimes. And extract duplicates for the purposes of description of the sample. In light of the results of the study the researcher recommended a series of proposals, it was the most important media awareness, create a specialty of information security, which will provide a dedicated staff continues cyber crimes and suggest solutions studied to reduce them. Besides a deterrent laws that prevent poor souls from committing crimes via the Internet.
\end{abstract}

Keywords: computer, internet, electronic crimes, Jordanian society

\section{Introduction}

The computer crimes and Internet crimes trendy that imposed itself on the global communities, and require the combined efforts of these communities in order to eliminate or reduce them. The Jordanian society like any other society that cannot protect himself from this scourge of crime and especially after the spread of the information revolution and the means of communication and modern technology has made the world a small village are open knows no geographical boundaries, political, social and others. Despite the importance of the Internet and computer in the latest dramatic changes in the lives of people of all walks of life, but it has downsides Delighted criminals professionals misuse against members of the community by committing behaviors criminal such as piracy, and crimes here are different from crimes recognized. The criminal does not use physical force in the implementation of his crime but uses Mind mental committing crime in many domains of political, economic, financial, military and other, without a major effort and a result and fear of growing these electronic crimes must all societies control through coordination and develop scientific plans and programs aimed at the organization. Such Strict control on the means of contact all, and enact strict legal legislation against their perpetrators.

\subsection{Problem of the Study}

The problem with the study is to clarify the nature of computer crimes and Internet, and the real size, and how to eliminate them or reduce them through different mechanisms, both on the legal and social levels. As will be discussed in this research size and style most common Internet crimes among Internet users in the community, especially with regard to sexual offenses and crimes of breakthroughs, financial crimes, and crimes create hostile or frequenting sites, and piracy. Identifying the most important features and characteristics of the perpetrators of these crimes.

\subsection{Questions of the Study}

And can achieve the purpose of this study by answering the following question:

"What is the nature of the crimes against the community by the computer and the Internet?"

And which fork to:

1) What is the size of the crimes practiced penetrations through the Internet? 
2) What is the size of the financial crimes practiced through the Internet?

3) What is the size of crimes create or attend or participate in the opposition or hostile websites practiced through the Internet?

4) What is the size of piracy practiced through the Internet?

\subsection{Objectives of the Study}

1) Identify the size of crimes practiced penetrations through the Internet?

2) Get on the size of financial crimes practiced through the Internet?

3) Get crimes create or attend or participate in the opposition or hostile websites practiced through the Internet?

4) Get on the size of the piracy practiced through the Internet?

\subsection{Significance of the Study}

The importance of this study of the theory in its focus on the youth as they are more class used for Internet and computer and have tendencies in the exercise of his crimes of what constitutes a danger to the community, as expected from the results of this study of the practice, face electronic crimes and to deal with them and reversing the spread of the recognize the reality of the crimes committed through the Internet and computers in society Ajloun, and help workers in the fields of social sciences and humanities and legal through the development of programs and policies targeted to address this criminal phenomenon, also draws researcher institutions involved and responsible for the attention to this phenomenon serious criminal and work to educate young people who are seen as more computer users online.

\subsection{Limitations of the Study}

The Study is limited by the following:

1) Time: the study has been in the academic year $2011 / 2012$.

2) Place: the study is restricted by sample consisted of (50) individuals youth from Ajloun Governorate in Jordan. The results are restricted only by this sample.

3) Human: The study is investigate the views of young people in Ajloun on Internet crimes committed by them or their peers and the 50 young, so you may change the results of this study class or change the size of the members of this study.

\section{Theoretical Background and Related Studies}

\subsection{Operational Definition}

Crime: every route of individual behavior is against the law and punishable.

Computer Crime: is the behavior or group behavior practiced by individuals illegally in order to obtain material gain or intangible and cause harm to members of the community.

Internet: is a form of modern electronic communication and the most widespread, through which the exchange of information between users around the world.

Computer: is a collection of interconnected devices with each other and integrated where it is stored set of data to be processed to accomplish certain functions.

The legal definition of the crime :it's "either the act of a crime, the law, or refrain from action required by law, and does not consider the act or omission crime in the eyes of man-made laws, but if it is punishable, according to the criminal legislation." (Odeh, 1980).

Computer Crime: "It's the kind of crimes that require special familiar techniques of computer and organize information to commit, or to investigate and sue Perpetrators ". (Mandourah, 1989)

It can also be defined as "any act of illegal computer they use it as a tool, or the subject of the crime." (Alibdaineh, 1999).

Internet: is that the electronic network consisting of a collection of networks that connect people and information of the through computers and digital devices that allow communication between one person and another and allow to retrieve this information" (Dimaggio et al., 2001).

Computer: can be defined as "a set of devices that are integrated with each other in order to run a set of data involved, according to the program has been developed in advance to obtain certain results" (Qashqush, 1992). 


\subsection{Types of Computer Crimes}

There many computer crimes and we will offer a range of types of crimes most commonly used by criminals.

1) computer viruses: The more Internet crimes common and dangerous, especially at the present time is an effective and quick to spread viruses, which is one kind of computer programs and limited programs on orders vandalized harmful device and its contents and that means easily the virus copies itself from one computer to another computer so that breed in large numbers. (Hilghley, 1999)

2) Breakthroughs: Lies seriousness in entering are not allowed to personal sites or official and computer networks through software available on the Internet and may not need to skill and technical expertise in high breakthroughs personal devices and e-mail is considered teenagers more class you use this type of crime, as happened in the U.S. in 1997 when a teenagers Breakthrough the air traffic control system and led to the disabling of the air navigation system (Wilsen, 2000)

$3)$ impersonation: This is a style of crimes modern relatively more dangerous and difficult to detect criminals and called his crime a crime of the millennium of the rapid spread of the commission in Institutions financial and trade, and through the use of personal identification of another person illegally until it becomes difficult to identify the offender's personality and facilitate the process of committing crimes are ordered easy on the internet. (Dawood, 1999)

4) pornographic websites: Internet is one of the most effective means of disseminating pornography through sexual display images and pornographic films negative impact on individuals and society, especially in conservative societies and that may affect the category of children who are those who are more prone to delinquency category and that porn sites have become a real problem and that these effects are not limited to the community without the other. (Adist,1999).

5) disable devices: (Al-Hajri, 2002). www.khayma.com

The process of disabling devices by sending a large number of messages in certain technical ways to be disabled devices which hampered their work.

6) harassment and prosecution: Are using e-mail and prosecute individuals by sending threatening letters and intimidating and harassing them, and characterized these crimes on the Internet easily possible to hide the identity of the offender, which helps in the spread of this crime and easy means of communication over the network.

7) lured and INQ: Often falls young Internet users from this type of crime through inducement to form friendships emotional or romantic or other relationships may transcend political boundaries of the community which is the offender in the state and the victim in another state.

8) defamation of and Reputation: Through the criminal publish confidential or false information about his victim and multiple methods used in this type of criminality such as the creation of Web sites contain information required to be published.

9) swindling and fraud: May use the Internet in fraud crimes by sending e-mails submitted an offer to sell or buy a commodity or provide fake or contribute to the fictitious investment projects and other commercial crimes.

\subsection{Related Studies}

Study Alimbideen and Abu Raiash (2008), entitled "Factors that limit the phenomenon of software piracy from the perspective of students," This study aimed to reveal the factors that limit the phenomenon of software piracy from the perspective of students Hashemite University, and is there statistically significant differences attributable to gender . The study sample consisted of (318) students of the Hashemite University students were randomly selected, and summarized the results of this study show that the religious faith of the most important factors that limit the phenomenon of software piracy, while the less influential factor is the treatment of hackers inferiority. There was no statistically significant differences due to gender.

Study El-Sheikh, Rashed, Al-Qudah \& Peace, 2006 entitled "software piracy in Jordan" This study aimed to detect software piracy in Jordan and develop solutions to limit their spread was orientations that while the responsibility for educating students rights intellectual property and the risks of piracy on the field of education and public awareness to members of the community are the responsibility of the public and private sectors and to make sure that increase awareness of the key ability to reduce piracy.

In the study of MasterCard Global (MasterCard International, 2004) entitled "Fraud in the continent of Asia in the first quarter of 2004", the aim of this study is to identify the credit card fraud and by type of crime, where 
crimes were divided into Seven forms, and the results of this study that the form of fraud highest in the credit card fraud, whether issued or accepted where some form almost $49 \%$, followed by the loss and theft of the card by $30 \%$.

Study Minshawi (2003), entitled "Internet crimes in Saudi society" and aimed to determine the size and style more cybercrime common among Internet users in Saudi society, especially with regard to sexual offenses and crimes of breakthroughs, financial crimes, and crimes create or frequenting sites hostile, and crimes piracy. Identifying the most important features and characteristics of the perpetrators of such crimes. Results showed that more crimes and Internet Practices common in Saudi society are crimes breakthroughs, followed by financial crimes and crimes sites hostile crimes and practices medium common, but the crimes and practices less common it sexual crimes and the practice of acts immoral.

Study Lesisko, (2003) entitled "disclosure of the reasons for draws individuals and organizations to piracy." The proposal included some of the solutions to reduce the phenomenon of awareness in schools, such as students and teachers of the responsibilities and restrictions to be taken into account when using the software, as well as making policies on software piracy is part of the copyright policies to benefit the despite the high cost.

study AARP center (2002) entitled "Identity Theft in the U.S." The study focused on forms of fraud resulting from the theft of identity information. The study found that in 2001 was most fraud is winning credit card fraud, where the figure reached $41.8 \%$. Followed by telephone fraud, and has reached to $\% 20.1$. And $13 \%$ is the percentage of bank fraud.

Study Akaddhi (2001), entitled "porn sites on the Internet and its impact on the individual and society" This study aims to find out visitors porn sites on the Internet and found out that there a large turnout very porn sites that four million seven hundred thousand visitors visiting the network per week, according to statistics company Playboy, and it turned out through the study that more users to porn sites, aged between 12-15 years, while a thread more porn web pages in search request.

Study Almasalmah (2001) entitled "Crimes of information systems and the Internet" a legal study and descriptive analysis of the content and findings of this study that Internet crimes include attacks on Web sites and impersonate individuals and impersonate sites and blatant sexuality and dumping messages and viruses.

Study Ramadan (2000) entitled "molesters people and the Internet", a legal study of some of the crimes of modern pop from the use of the Internet and displays them to the international laws U.S. and French and the possibility of applying the Egyptian law on such crimes and responsibility of criminal cyber crime and the study found that there are practical difficulties the application of traditional ideas set forth in the criminal laws and their application in terms of place and jurisdiction.

\subsection{What Makes This Study More Significant than the Related Study?}

The whole previous studies have looked at computer crime and Internet but may vary our current from previous studies (Alimbideen \& Raiash, 2008; Al-Qudah \& Pace, 2006; Lecico, 2003), because they are seeking the crimes of piracy and software. While (peaceful 2002 study, and the study of September 2000), seeking in crimes and online information systems from the perspective of legal and legislative action. The current study agreed with some previous studies, such as (AARP, 2002; MasterCard, 2004). Porn sites crimes and fraud. But the study was (Minshawi, 2003; Akaddhi, 2001) studies closer to the subject of the study. The most important characteristic of this study from previous studies are discussed in computer crimes and the Internet together in Jordanian society, and tried to cover the subject of the study in terms of social, legal, and computer.

\section{Methods and Procedures}

The population: The population of the study consisted of the youth people (male and female) in Ajloun Governorate .

The sample: The sample of the study include (50) member of the study sample are as shown in Table 1.

Table 1 . The study sample/repetition rate categories

\begin{tabular}{cccc}
\hline & Categories & Repetition & Percentage \\
\hline \multirow{3}{*}{ School year } & First & 24 & $\% 48$ \\
& Again & 8 & $\% 16$ \\
& Third or more & 18 & $\% 36$ \\
\multirow{2}{*}{ Specialization } & Scientific disciplines & 40 & $\% 80$ \\
& Humanitarian disciplines & 10 & $\% 20$ \\
\hline
\end{tabular}


Study Tools: this study will be used questionnaire tool to achieve the objectives of the study, which aims to identify the most computer crimes and Internet prevalent.

Believe study tools: Make sure the sincerity, sincerity of content will be used where the tool will display a second (resolution) in its initial form, the arbitrators who are specialists in the science of meeting and experiment and law, and any other professionals can contribute to the upgrading of a study tool. The results were as follows:

Table 2. Coefficients stability study tool

\begin{tabular}{lll}
\hline No. & Dimension & Reliability coefficient \\
\hline 1 & Penetrations crimes & 0.87 \\
2 & Financial Crimes & 0.84 \\
3 & $\begin{array}{l}\text { Create crimes or attend or participate in the opposition or hostile websites } \\
\text { committed on the Internet }\end{array}$ & 0.86 \\
4 & Piracy & 0.61 \\
\hline
\end{tabular}

Thus, the rate stability main content Questionnaire the high came and express excellent rate stability.

Study Methodology: descriptive method will be used analytical and statistical approach. We will use this research descriptive analytical method as a basis for addressing the problem of search, and through our review of research and studies related to Internet crimes with cash and proposing a solution when it is required.

\section{Statistical Reference}

For the answer to the first question and the second, third and fourth were used averages and standard deviations and ranks with the aim of identifying the most common Internet crimes.

And extract duplicates for the purposes of description of the sample.

Results of the study: the researcher calculates averages and standard deviations and identified grade, class and level of approval for each study areas:

Table 3. Averages and standard deviations of the areas

\begin{tabular}{lll}
\hline Domain & The arithmetic mean & Standard deviation \\
\hline $\begin{array}{l}\text { 1. What is the size of the breakthroughs that crimes } \\
\text { committed on the Internet? }\end{array}$ & 0.51 \\
$\begin{array}{l}\text { 2. What is the size of the financial crimes committed on } \\
\text { the Internet? }\end{array}$ & 0.42 \\
$\begin{array}{l}\text { 3. What is the size of crimes create or attend or participate } \\
\text { in the opposition or hostile websites committed on the } 1.40\end{array}$ \\
$\begin{array}{l}\text { Internet? } \\
\text { 4. What is the size of the piracy crimes committed on the }\end{array}$ \\
Internet?
\end{tabular}

Results related to the first question: What is the size of the breakthroughs that crimes practiced on the Internet?

To answer this question were calculated averages and standard deviations were identified ranks. The results were as follows: 
Table 4. Averages and standard deviations to paragraphs crimes infiltrations

\begin{tabular}{|c|c|c|c|c|}
\hline No. & Paragraph & $\begin{array}{l}\text { arithmetic } \\
\text { mean }\end{array}$ & $\begin{array}{l}\text { Standard } \\
\text { deviation }\end{array}$ & $\begin{array}{l}\text { Rank } \\
\text { paragraph }\end{array}$ \\
\hline 1 & $\begin{array}{l}\text { Have you ever created someone page to slander one of your } \\
\text { relatives or acquaintances on the internet? }\end{array}$ & 1.42 & 0.78 & 4 \\
\hline 2 & Have you ever used ways to access blocked sites? & 1.54 & 0.70 & 3 \\
\hline 3 & $\begin{array}{l}\text { Have you ever used personal hide programs while surfing the } \\
\text { Internet? }\end{array}$ & 2.02 & 0.89 & 1 \\
\hline 4 & $\begin{array}{l}\text { Have you ever impersonate others while browsing or use } \\
\text { e-mail? }\end{array}$ & 1.58 & 0.70 & 2 \\
\hline 5 & Have you participated in the destruction of any site? & 1.24 & 0.55 & 7 \\
\hline 6 & Have you ever show your destruction? & 1.32 & 0.65 & 6 \\
\hline 7 & $\begin{array}{l}\text { Have you ever break any official government site, } \\
\text { commercial, personal? }\end{array}$ & 1.36 & 0.69 & 5 \\
\hline 8 & Have you ever break any personal device over the Internet? & 1.42 & 0.70 & 4 \\
\hline 9 & Have you ever been your personal online penetration? & 1.54 & 0.78 & 3 \\
\hline \multicolumn{2}{|r|}{ College degree } & 1.49 & 0.51 & \\
\hline
\end{tabular}

Averages were calculated and standard deviations for each paragraph of the first area of the areas of study tool, came the arithmetic mean of the field (1.49) and standard deviation (0.51). The table (4) that paragraph (3), which stipulates, "Have you ever used programs hide personal while surfing the Internet?", Came level first, where he was the arithmetic average have (2.02), while came paragraph (4) in the second, which stipulates "Have you ever impersonate others while browsing or use e-mail?" An average Wish (1.58), and came paragraph (5), which stipulates "Have you participated in the destruction of any site?" Last a mean level reached (1.24).

Results related to the second question: What is the size of the financial crimes practiced on the Internet?

To answer this question were calculated averages and standard deviations were identified ranks. The results were as follows:

Table 5. Arithmetic means and standard deviations for the paragraphs of financial crimes

\begin{tabular}{|c|c|c|c|c|}
\hline No & Paragraph & $\begin{array}{l}\text { arithmetic } \\
\text { mean }\end{array}$ & $\begin{array}{l}\text { Standard } \\
\text { deviation }\end{array}$ & $\begin{array}{l}\text { Rank } \\
\text { paragraph }\end{array}$ \\
\hline 10 & $\begin{array}{l}\text { Have you ever received or used the online credit cards to others } \\
\text { without their permission? }\end{array}$ & 1.42 & 0.78 & 1 \\
\hline 11 & Have you ever took one online on your credit card? & 1.30 & 0.58 & 3 \\
\hline 12 & Have you ever practiced gambling on the Internet? & 1.18 & 0.38 & 4 \\
\hline 13 & $\begin{array}{l}\text { Have you ever you and without permission to change any data or } \\
\text { information about you or others online for personal gain? }\end{array}$ & 1.12 & 0.32 & 5 \\
\hline 14 & $\begin{array}{l}\text { Have you ever entry sites on the drug trade or cultivation or } \\
\text { promote them? }\end{array}$ & 1.18 & 0.52 & 4 \\
\hline 15 & Have you ever enter the sites for money laundering? & 1.36 & 0.69 & 2 \\
\hline \multicolumn{2}{|c|}{ College degree } & 1.26 & 0.42 & \\
\hline
\end{tabular}

Averages were calculated and standard deviations for each paragraph of the second area of the areas of study tool, came the arithmetic mean of the field (1.26) and standard deviation (0.42).

The table (5) to paragraph (10), which stipulates, "Have you ever got or used online on credit cards to others 
without their permission?", Came level first, where he was the arithmetic average have (1.42), while came paragraph (15) in the second, which stipulates "Have you ever enter the sites for money laundering?" An average Wish (1.36), and came paragraph (13), which stipulates "that you ever without permission to change any data or information about you or others online for personal gain?" Last a mean level reached (1.12).

Results on the third question: What is the size of crimes create or attend or participate in opposition or hostile websites exerted on the Internet?

To answer this question were calculated averages and standard deviations were identified ranks. The results were as follows:

Table 6. Arithmetic means and standard deviations for crimes paragraphs create or attend or participate in opposition or hostile websites

\begin{tabular}{|c|c|c|c|c|}
\hline No. & Paragraph & $\begin{array}{l}\text { arithmetic } \\
\text { mean }\end{array}$ & $\begin{array}{l}\text { Standard } \\
\text { deviation }\end{array}$ & $\begin{array}{l}\text { Rank } \\
\text { paragraph }\end{array}$ \\
\hline 16 & $\begin{array}{l}\text { Have you ever create an opposition political site on the } \\
\text { Internet? }\end{array}$ & 1.24 & 0.55 & 4 \\
\hline 17 & $\begin{array}{l}\text { Have you ever voluntarily participate in the mailing list for } \\
\text { any refund or political shows? }\end{array}$ & 1.18 & 0.38 & 5 \\
\hline 18 & Have you ever created a religious site or list? & 1.48 & 0.78 & 2 \\
\hline 19 & $\begin{array}{l}\text { Are you ever going to join the mailing list for any religious } \\
\text { site or list? }\end{array}$ & 1.68 & 0.86 & 1 \\
\hline 20 & Have you ever created a site against the person or entity? & 1.46 & 0.70 & 3 \\
\hline \multicolumn{2}{|r|}{ College degree } & 1.40 & 0.54 & \\
\hline
\end{tabular}

Averages were calculated and standard deviations for each paragraph of the third domain of the areas of study tool, came the arithmetic mean of the field (1.40) and standard deviation (0.54).

The table (6), paragraph number (19), which stipulates, "Have you ever participate in the mailing list to any site or list religious?", Came level first, where he was the arithmetic average have (1.68), while came paragraph (18) in the second, which stipulates "Have you ever created a religious site or list?" An average Wish (1.48), and came paragraph (17), which stipulates, "Have you ever voluntarily participate in the mailing list for any refund or political shows?" Last a mean level reached (1.18).

Results for the fourth question: What is the size of piracy practiced on the Internet?

To answer this question were calculated averages and standard deviations were identified ranks. The results were as follows:

Table 7. Averages and standard deviations of paragraphs piracy

\begin{tabular}{lllll}
\hline No & Paragraph & $\begin{array}{l}\text { arithmetic } \\
\text { mean }\end{array}$ & $\begin{array}{l}\text { Standard } \\
\text { deviation }\end{array}$ & $\begin{array}{l}\text { Rank } \\
\text { paragraph }\end{array}$ \\
\hline 21 & $\begin{array}{l}\text { Have you ever download any software or pirated material } \\
\text { online? }\end{array}$ & 1.44 & 0.76 & 2 \\
22 & $\begin{array}{l}\text { Have you ever used helps to continue to run the original } \\
\text { software illegally? }\end{array}$ & 1.60 & 0.78 & 1 \\
$\quad \begin{array}{l}\text { Have you ever worked quite similar sites to sites other people } \\
\text { on the internet? }\end{array}$ & 1.42 & 0.70 & 3 \\
College degree & 1.48 & 0.56 & \\
\hline
\end{tabular}

Averages were calculated and standard deviations for each paragraph of the fourth area of the areas of study tool, 
came the arithmetic mean of the field (1.48) and standard deviation (0.56).

The table (7) that the paragraph number (22), which stipulates, "Have you ever used helps to continue to run the original software illegally?", Came level first, where he was the arithmetic average have (1.60), while came Paragraph (21) in second place, which stipulates "Have you ever download any software or pirated material online?" An average Wish (1.44), and came paragraph (23), which stipulates, "Have you ever worked quite similar sites to sites other people on the Internet?" Last a mean level reached (1.42).

\section{The Findings of the Study}

The study came up with the following findings:

1) showed the study sample that more computer crimes and Internet deployed with regard to crimes breakthroughs is hide personal, where it came from a mean (2.02), followed by impersonating others where it came from a mean (1.58), and finally with regard to crimes breakthroughs came offense destruction sites ranked least prevalent where you got the arithmetic average was (1.24).

2) showed the study sample that more computer crimes and Internet deployed with respect to financial crimes is the use of credit cards over the Internet, where it came from a mean (1.42), followed by access to sites with money laundering where it came from a mean (1.36), and finally with regard to crimes of financial The change personal data for a particular person to achieve material gains where you got the arithmetic average was (1.12).

3) regarding crimes create or attend or participate in the sites of opposition or anti committed on the Internet showed the sample that is equivalent to (1.68) may participate in the mailing list for the site or a list of religious, and some of them created the religious sites, also showed that subscribe to political opposition is not a great crime spread among the study sample where the arithmetic average (1.18). Crimes are the lowest in the opposition sites.

4) The sample of the study showed that a large proportion of them have been used helps to continue to run the original software illegally, where the arithmetic average (1.60), also download pirated software is common among the sample.

5) showed the study sample that more crimes prevalent among the study sample are crimes penetrations, where arithmetic average total for this area (1.49), followed by hacking a mean (1.48), and then comes after the establishment or attend or participate in the sites of opposition or hostile committed on the Internet, arithmetic average (1.40), and finally the financial crimes, arithmetic average (1.26).

\section{Recommendations}

1) Invite universities and collages to establish information security specialization, which will provide a dedicated staff continues cyber crimes and able to propose solutions studied to reduce them.

2) Holding workshops and awareness seminars and media, to reduce the risk of damage and crimes committed by the computer and the Internet, and the dire consequences for those who provide them.

3) Jordanian legislator's call for a deterrent laws that prevent poor souls from committing crimes via the Internet.

4) Invitation of the Ministry of Education in Jordan include curriculum intellectual property rights law and make them aware of the laws that criminalize piracy over the Internet and computer crimes in general

5) Call researchers to conduct similar studies on a larger sample to different segments of the Jordanian society

\section{References}

Adist, C. K. (1999). Internetpornography Addiction. Retrieved from http://www.chemistry.vt.edu/chem

Akaddhi, M. A. (2001). Porn sites on the Internet and its impact on the individual and society. Retrieved from http://www.minshawi.com/gadhi.htm

Alibdaana, D. (1999). Computer and Internet crimes, Research Scientific Symposium to study criminal phenomena developed and ways to address them. Naif Arab Academy for Security Sciences, Tunisia.

Almasalmah, H. A. (2001). Crimes and online information systems. Scientific research and legal provider to win the title of professor in the law. The Office of Khansa, Daraa, Syria.

Dahir, D. H. (1999). Information Systems crimes. Riyadh: Naif Arab Academy for Security Sciences.

Dimaggio, P., Hargittai, E., Neuman, W., \& Robinson, J. (2001). Social Implication of the Internet. Annual Review of Sociology, 307-348. http://dx.doi.org/10.1146/annurev.soc.27.1.307

El-Sheikh, A., Rashed, A., \& Al-Qudah, B., \& Peace, A. G. (2006). An Exploratory Study of Software Piracy in 
Jordan. The Electronic Journal on Information Systems in Developing Countries, 4, 18.

Hajri, \& Ropause. (2002). Cyber crimes, and a research paper. Retrieved from http://www.khayma.com

Highley, R. (1999). Viruses: The internet's Illness. Retrieved from http://www.chemistry.vt.edu/chem

Huda, Q. (1992). Computer-mail crimes in comparative legislation (1st ed.). Renaissance House, Cairo.

Lesisko, L. J. (2003). Analyzing Software Piracy in Education.

Mandourah, M. M. (1989). Cybercrime mechanism, automatic cycle computer virus. United Hobo Office, Riyadh.

Master Card International. (2004, First Quarter). Asia / Pacific Security and Risk services. SANTLUIS, USA.

Menshawi, M. A. A. (2003). The size and style of the most common Internet crimes among Internet users in Saudi society, and a research paper.

Odeh, A. (1980). Islamic criminal legislation. Beirut message Foundation, I.

Public Policy Institute. (2002). Identity Theft: Experience of Older Complaints. Retrieved July, 2004, from http://www.ou.edu/oupd/idthef.htm

Raiash, A., Nasser, G. A., \& Dreams, M. S. (2008). Factors that limit the phenomenon of software piracy from the point of view of students, and a research paper.

Ramadan, M. (2000). Crimes against the people and the Internet. House Arab Alnhzh, Cairo.

Wilson, C. (2000). Holding management accountable: anew policy for protect against computer crime. Proceedings of the national Aerospace and Electronics Conference, USA.

\section{Copyrights}

Copyright for this article is retained by the author(s), with first publication rights granted to the journal.

This is an open-access article distributed under the terms and conditions of the Creative Commons Attribution license (http://creativecommons.org/licenses/by/3.0/). 